\title{
"BUKAN HANYA SEKEDAR KUMPULAN KUTIPAN WAWANCARA": MENINGKATKAN KUALITAS RISET KUALITATIF BIDANG PSIKOLOGI DI INDONESIA
}

\author{
Made Diah Lestari \\ Fakultas Psikologi, Universitas Udayana, Jl. Raya Kampus Unud Jimbaran, Kec. Kuta Selatan, Kab. Badung, Bali 80361, Indonesia
}

Korespondensi: mdlestari@gmail.com

\section{“MORE THAN JUST A VERBATIM": ENHANCING THE QUALITY OF INDONESIAN PSYCHOLOGICAL QUALITATIVE STUDIES}

\section{Abstract}

Relativity is the keyword that describes the intersection of indigenous psychology and qualitative approach. The paradigm upheld by qualitative studies appreciates the multiple, subjective realities, which is often blamed as less scientific and less reliable by the hegemonic of quantitative paradigm (positivism). I critically analyzed both the quantity and the quality of qualitative studies published in the Jurnal Psikologi Ulayat: Indonesian Journal of Indigenous Psychology. During 2017-2020, there has been a relatively proportional number of qualitative and quantitative reports. Despite the proportional numbers, there are still many rooms for improvement that is worth noting to enhance the quality of a qualitative study. In this editorial note, I emphasize few arguments that highlight the imperative of integrating critical tradition to shape the meaning and holistic findings of qualitative studies in constructing respondents' reality.
Manuscript type: Editorial Note

Article history:

Received 21 March 2021

Received in revised form 31 March 2021

Accepted 7 April 2021

Available online 8 April 2021

\section{Keywords:}

critical tradition

indigenous

qualitative research

\begin{abstract}
Abstrak
Relativitas merupakan kata kunci yang menggambarkan irisan antara psikologi ulayat dan pendekatan penelitian kualitatif. Paradigma pendekatan kualitatif mengapresiasi keberagaman dan subjektivitas realitas, yang oleh hegemoni paradigma kuantitatif (positivisme) dianggap kurang ilmiah dan kurang ajeg. Saya mengkritisi perkembangan kualitas dan kuantitas studi kualitatif pada artikel-artikel yang diterbitkan di Jurnal Psikologi Ulayat: Indonesian Journal of Indigenous Psychology. Pada periode 2017-2020, jumlah artikel kualitatif pada jurnal ini menempati posisi yang sebanding dengan artikel dengan pendekatan lainnya. Meski jumlah yang sebanding ini menunjukkan minat dan persepsi yang positif terhadap pendekatan kualitatif, namun masih ada beberapa ruang perbaikan yang perlu dipikirkan untuk meningkatkan kualitas studi kualitatif. Dalam catatan editorial ini, saya mengedepankan beberapa argumen yang menekankan pentingnya mengintegrasikan tradisi kritik untuk membuat studi kualitatif lebih bermakna dan holistik dalam menggambarkan realita yang dikonstruksikan subjek penelitian.
\end{abstract}

Kata Kunci: kualitatif, tradisi kritik, ulayat

Pada tahun 2020, Jurnal Psikologi Ulayat: Indonesian Journal of Indigenous Psychology (JPU) menambahkan satu bagian penting dalam sistematika penulisan artikel yang diterbitkan. Bagian tersebut adalah "Dampak dan Implikasi Ulayat". Bagian ini bertujuan untuk menunjukkan kepada pembaca mengenai bagaimana lingkup dan hasil penelitian memberikan dampak atau kontribusi dalam konteks Indonesia. Tentu saja hal ini sangat relevan dengan nama yang diusung oleh jurnal ini: "ulayat". Kata ulayat sendiri diadopsi dari istilah antropologi dan hukum yang ditetapkan penggunaannya pada Kongres Ikatan Psikologi Sosial di Universitas Indonesia pada tahun 1999 (Sarwono, 2012). Untuk keperluan praktis, bagian Dampak dan Implikasi Ulayat memudahkan bagi pembaca, terutama dari kalangan praktisi atau industri, untuk mengetahui bagaimana hasil penelitian tersebut dapat diterjemahkan dalam perumusan solusi dan kebijakan 
yang kontekstual, termasuk menentukan arah riset ke depannya. Tentu saja tidak lupa manfaat bagi pihak lain yang berkepentingan (seperti: asesor jurnal) untuk mengidentifikasi kesesuaian artikel yang diterbitkan dengan lingkup dan tujuan jurnal.

Semangat ulayat diusung oleh JPU sejak saat berdirinya. Diharapkan semangat ini tercermin dalam artikel-artikel yang diterbitkan. Selama kurun waktu JPU hadir, semangat ini terlihat dalam setidaknya dua manifestasi dalam memaknai ulayat. Pertama, pemaknaan ulayat yang mengedepankan komparasi antara studi terdahulu di luar Indonesia dengan studi yang secara khusus dilakukan di dalam konteks Indonesia. Kedua, pemaknaan ulayat yang berfokus pada pemahaman bahwa Indonesia menyajikan kekhasan, yang hanya bisa ditemukan, dibangun, dan dimaknai dalam di dalam konteksnya. Dalam perjalanannya, pemahaman yang pertama sepertinya lebih populer bagi para kontributor JPU jika dibandingkan dengan yang kedua. Namun apabila dicermati, definisi ulayat lebih mengacu kepada pendekatan yang kedua: budaya etnik, asli, yang berkembang di suatu wilayah tertentu, belum bermigrasi, bebas kolonialisasi, dan dirancang untuk orang-orang di wilayah itu sendiri (Sarwono, 2012; Stewart, 2018). Profesor Sarlito Wirawan Sarwono, sebagai salah satu pemrakarsa JPU, menegaskan pentingnya paradigma penelitian dalam riset-riset psikologi terkait budaya. Ia menegaskan bahwa psikologi dalam konteks budaya tertentu, sangat kental dengan nuansa relativitas (Sarwono, 2012). Pernyataan ini menjadi pijakan bagi catatan ini untuk membahas bagaimana ulayat beririsan dengan studi kualitatif di Indonesia. Bagi saya, penelitian kualitatif menjadi salah satu pendekatan penting dalam mengembangkan penelitian ulayat di Indonesia.

Saat memulai sebuah penelitian, satu pertanyaan yang selalu ada di benak kita adalah: bagaimana kita akan 'mendekati' apa yang ingin kita teliti? Sederhananya, penelitian bertujuan untuk menemukan jawaban dari pertanyaan tentang realitas yang ada di dunia ini, sehingga bagaimana kita memandang realitas memberi sudut pandang yang penting untuk dimiliki seorang peneliti. Penjelasan ini dikenal dengan ontologi. Posisi peneliti dalam ontologi menentukan bagaimana ia akan menjawab pertanyaan penelitian. Dengan kata lain, perspektif ini mengarahkan peneliti dalam membangun metode penelitiannya: apakah realitas dipandang sebagai suatu kebenaran tunggal atau dimungkinkan beragam realitas dalam dunia ini sesuai dengan versi saya, dia, atau mereka. Dalam konteks ini, dikotomi positivisme (kuantitatif) - konstruksivisme (kualitatif) menjadi hal populer dalam penelitian-penelitian psikologi. Di Indonesia, atau mungkin juga di belahan dunia lainnya, keleluasaan untuk menggunakan dua paradigma ini secara bergantian atau saling mendukung satu sama lain menjadi sebuah hak istimewa bagi psikologi dibandingkan dengan ilmu lainnya. Hak istimewa ini hadir bukan tanpa tantangan. Bagi saya pribadi, tidak mudah 
menjadi peneliti dalam tradisi kualitatif karena saya berkarier di sebuah lembaga pendidikan tinggi dengan tradisi positivisme kuat, yang menekankan pentingnya objektivitas dan pola pikir deduktif, sehingga seolah-olah mengglorifikasi desain eksperimen terkontrol.

Kurangnya pemahaman akan paradigma konstruktivisme kerap melahirkan kesalahan persepsi di mana studi kuantitatif dianggap lebih ilmiah dibanding studi kualitatif. Asumsi ini bukan hanya asumsi pribadi sebagian orang, tetapi secara nyata juga dikeluhkan oleh beberapa pengelola jurnal yang mendapati rejected rate yang tinggi pada artikel-artikel kualitatif, yang tidak jarang disebabkan oleh hegemoni kuantitatif di kalangan reviewer (LaRossa dkk., 2014; Sidhu dkk., 2017). Masih kuat dalam ingatan saya ketika seorang peserta semiloka mengomentari dengan cenderung memandang sebelah mata mengenai materi yang saya sampaikan terkait penelitian kualitatif. Semiloka ini adalah suplemen bagi penelaah proposal penelitian, sehingga dapat ditebak bahwa pesertanya adalah calon penelaah sejawat proposal penelitian di perguruan tinggi. Di akhir sesi, peserta itu berkomentar bahwa selama ini beliau selalu memberikan poin rendah bagi proposal studi kualitatif karena metodenya dianggap lemah: tidak ada kontrol terhadap variabel, tidak ada kriteria inklusi, ekslusi, tidak ada teori yang ajeg, tidak ada informasi terkait realiabilitas, validitas, dan analisis data yang membingungkan karena tidak ada analisis statistik atau parameter yang dapat dipercaya (gagal paham yang khas ketika seseorang memaksakan paradigma positivisme ke dalam paradigma konstruktivisme). Di kesempatan berbeda, saat saya membimbing skripsi lintas program studi, saya diminta untuk mengarahkan mahasiswa menggunakan pendekatan kuantitatif karena hanya pendekatan tersebut yang diizinkan. Pendekatan kuantitatif dinilai lebih kompleks, lebih layak untuk sebuah tugas akhir. Menariknya, dua peristiwa ini tidak terjadi berpuluh-puluh tahun yang lalu, namun terjadi kurang dari 5 tahun yang lalu.

Dalam komunitas JPU, kita tidak melihat marginalisasi ini terjadi pada penelitian kualitatif. Sebaliknya, kita merayakan kehadirannya. Salah satunya terlihat dari sebanyak 21 artikel kualitatif yang diterbitkan oleh JPU dari kurun waktu 2017-2020, hampir setengah dari jumlah keseluruhan artikel yang diterbitkan pada kurun waktu yang sama.

Lalu apakah kita sudah merayakannya dengan sukacita? Kualitatif adalah pendekatan yang sangat dinamis - saya memahaminya sebagai sebuah seni. Dengan pemahaman ini, terkadang melakukan penelitian kualitatif tidak cukup hanya dibekali dengan pengetahuan tentang bagaimana melakukan dan melaporkannya, tetapi juga memerlukan keterampilan setidaknya untuk membangun relasi dengan partisipan penelitian, memulai wawancara, mendengarkan dan memahami realitas mereka, serta berani untuk tampil berbeda. Yang terakhir adalah yang paling menantang. Satu hal yang membedakan kualitatif dari kuantitatif adalah natur studinya yang bersifat induktif, sehingga arah diskusinya ditentukan oleh data (data driven). Temuan-temuan 
kualitatif diarahkan oleh bagaimana data berbicara, bukan diarahkan oleh teori yang sudah ada. Berbicara di tataran data ini tidak mudah bagi peneliti yang terbiasa dinyamankan oleh teori-teori yang dinilai sudah ajeg. Hal ini membuat penelitian yang didesain sejak awal sebagai sebuah penelitian yang mengkonstruksi realitas partisipan, berakhir dengan temuan yang konform dengan lensa teori yang sudah ada atau hanya sekadar deskripsi kutipan-kutipan wawancara tanpa menampilkan kemampuan analisis dan sintesis peneliti (Tong dkk., 2007). Inilah yang masih terjadi pada sebagian besar naskah JPU, sehingga artikel yang mencoba menemukan, membangun, dan memaknai realitas dalam konteks Indonesia masih sangat sepi, ibarat menemukan air di gurun pasir.

Dengan kondisi seperti ini, perayaan kualitatif dalam ilmu psikologi di Indonesia belumlah megah, dan mungkin melewatkan beberapa unsur yang sebetulnya berpotensi untuk membuat ini menjadi megah, seperti kekayaan budaya, keragaman suku, kompleksitas struktur sosial, kesenjangan kondisi ekonomi, variasi generasi, dan berbagai warna keyakinan. Selama ini, temuan penelitian kualitatif hanya mencoba menemukan apa realitas itu dalam kacamata partisipan (yang celakanya disesuaikan lagi dengan teori yang sudah ada, sehingga masih berpijak sebelah kaki pada perspektif positivisme), dan masih belum mencoba menjawab pertanyaan terkait bagaimana realitas itu dikonstruksi oleh partisipan dan mengapa (untuk tujuan apa) realitas itu dikonstruksi? Dua pertanyaan terakhir terkait bagaimana dan mengapa berada dalam tradisi kritik (Langdridge, 2008). Mungkin ini menjadi tantangan dan kondisi ideal yang penulis bayangkan menjadi pedoman untuk penelitian kualitatif di Indonesia. Dengan perkembangan yang ada sejauh ini, mengembangkan tradisi kritik tidaklah mudah di saat kemampuan analisis dan sintesis masih berbau deskriptif dan positivisme. Menjadi pekerjaan rumah yang sangat besar untuk mendorong peneliti mengeluarkan suara mereka tanpa merusak realitas partisipan.

Tradisi kritik sebetulnya bukan hal yang baru. Harus diakui, peneliti-peneliti yang berkecimpung di bidang filsafat, sosiologi, ataupun kajian feminisme lebih progresif dibandingkan dengan psikologi. Namun, jika kita mendorong diri untuk berani keluar dari kecenderungan hanya mendeskripsikan temuan dan mencoba untuk naik ke level interpretatif secara perlahan, bukan tidak mungkin, kita pasti bisa melakukannya. Realitas mungkin beragam, subjektif, dan sangat kontekstual, namun selalu ada dinamika bagaimana realitas itu dibangun, bagaimana dampaknya bagi individu, dan selalu bertujuan. Dengan lensa ini, sebagai peneliti kita tidak menerima realitas partisipan sebagai sesuatu yang diterima begitu saja, tetapi sesuatu yang dikonstruksi untuk tujuan tertentu: melindungi diri, mempertahankan hidup, merepresentasikan persepsi sebagai korban, atau membangun citra. Pemahaman ini akan mengarahkan kita untuk memandang individu sebagai suatu kesatuan yang holistik. Temuan yang holistik pada akhirnya mampu mengarahkan hasil-hasil 
penelitian untuk dapat diterapkan untuk kebutuhan praktis, salah satunya mempromosikan kesejahteraan psikologis individu.

Temuan penelitian kualitatif sebaiknya tidak hanya berhenti di atas kertas publikasi yang dibagikan antar sesama akademisi. Idealnya, temuan ini perlu didiseminasikan kepada masyarakat luas dan pemangku kebijakan. Sepertinya halnya ulayat, kualitatif adalah perihal merayakan keberagaman, merayakan ke-Indonesia-an kita yang harus dinikmati dan dirasakan dampaknya bagi semua.

\section{REFERENSI}

Langdridge, D. (2008). Phenomenology and critical social psychology: Directions and debates in theory and research. Social and Personality Psychology Compass, 2(3), 1126-1142. https://doi.org/10.1111/j.1751-9004.2008.00114.x

LaRossa, R., Goldberg, A., Roy, K., Sharp, E., \& Zvonkovic, A. (2014). Qualitative Research Commission Report, 1-12.

Sarwono, S. W. (2012). Psikologi ulayat. Jurnal Psikologi Ulayat: Indonesian Journal of Indigenous Psychology, 1(1), 1-16. https://doi.org/10.24854/jpu2

Sidhu, K., Jones, R., \& Stevenson, F. (2017). Publishing qualitative research in medical journals. The British Journal of General Practice, 67(658), 229-230. https://doi.org/10.3399/bjgp17X690821

Stewart, G. (2018). What does 'indigenous' mean, for me? Educational Philosophy and Theory, 50(8), 740-743. https://doi.org/10.1080/00131857.2017.1302050

Tong, A., Sainsbury, P., \& Craig, J. (2007). Consolidated criteria for reporting qualitative research (COREQ): A 32-item checklist for interviews and focus groups. International Journal for Quality in Health Care, 19(6), 349-357. https://doi.org/10.1093/intqhe/mzm042 